\title{
Skin Eschar
}

National Cancer Institute

\section{Source}

National Cancer Institute. Skin Eschar. NCI Thesaurus. Code C96218.

A crust that covers necrotic tissue in the skin that is caused by a burn or gangrene. 